Trabajos y Comunicaciones, 2da. Época, Nº 45, e036, marzo 2017. ISSN 2346-8971

Universidad Nacional de La Plata.

Facultad de Humanidades y Ciencias de la Educación.

Departamento de Historia

\title{
La sociedad porteña y sus conformaciones familiares. Fines del siglo XVIII y principios del XIX
}

\author{
The Buenos Aires society and its family conformations. End of the \\ 18th century and early 19th
}

\section{Macarena Belén Jaciuk*}

\section{PALABRAS CLAVE}

Familias

Fuentes para la historia

Planificación

Tercer año

Escuela secundaria

* Facultad de Humanidades y Ciencias de la Educación - Centro de Historia Argentina y Americana - Universidad Nacional de La Plata, Argentina | macarenajaciuk@gmail.com

\section{RESUMEN}

Este trabajo pretende brindar ideas y algunos materiales, para elaborar una planificación completa de una clase destinada a estudiantes del tercer año (Escuela Secundaria). Respondiendo a los requisitos del Diseño Curricular se adopta la utilización de fuentes primarias del período tardo colonial del Río de la Plata, con el objetivo de impulsar una reflexión respecto de las formaciones familiares tanto en la Historia como en la actualidad. Se intenta con ello promover el reconocimiento y aceptación de las diversidades en una sociedad compleja.

KEYWORDS

Families

History sources

Planification

Third year

Secondary school

\section{ABSTRACT}

This work aims to give ideas and some materials to elaborate a full planification of a class destined to third year students (Secondary School). Responding to the requirements of the Curriculum Design, the use of primary sources of the late colonial period of the Rio de la Plata is adopted, with the aim of impulse a reflection of the family conformations both in history and at present. It tries to promote the recognition and acceptance of diversity in a complex society.

Recibido: 22 de noviembre de 2016 | Aceptado: 27 de febrero de 2017 | Publicado: 27 de marzo de 2017 


\section{Introducción:}

"Enseñar no es transferir conocimientos sino crear las posibilidades para su propia producción o construcción”. En el caso de la Historia, el saber que se pretende enseñar "no es solo el de quien constata lo que ocurre sino el de quien interviene como sujeto de ocurrencias. No soy solo objeto de la Historia sino que soy igualmente su sujeto. En el mundo de la Historia ... compruebo no para adaptarme sino para cambiar” (Freire, 2010: 47 y $73-74$ respectivamente)

Esta propuesta de clase está destinada para alumnos de tercer año del Colegio Secundario y se trabaja con el eje de Ciencias Sociales Historia del Diseño Curricular para $3^{\circ}$ año (ES), cual es el de abordar el estudio de algunos aspectos particulares de la sociedad porteña de fines del siglo XVIII y principios del XIX. ${ }^{1}$ En el mencionado Taller de Enseñanza de la Historia se proponía “descubrir y enseñar la historia con fuentes" de tal manera que cada una de las unidades contenía un tipo de documento -testimonios, biografías, expedientes de la justicia, imágenes iconográficas, etc.-, acompañado por una bibliografía teórica e histórica que permitiera ubicar, tanto el contexto histórico, como incorporar algunos elementos para caracterizar y luego, analizar el potencial informativo del documento.

No se trata de presentar una planificación completa y/o cerrada de la clase puesto que para tal fin, necesitaríamos conocer-diagnosticar mejor el curso, o sea a los destinatarios. " Es importante tener en cuenta que el profesor debe prestar atención a las concepciones de los alumnos, tanto a las que poseen antes de que comience el proceso de aprendizaje como a las que irán generando durante este proceso.” (Carretero, 2009:57)

Por lo tanto, el propósito es el de retomar fuentes primarias o secundarias, para ofrecer a los alumnos un análisis más rico del proceso histórico. Cabe destacar que si bien se ha tomado en cuenta el tiempo de la clase, esta no se plantea de manera rígida. De ese modo se podrán adecuarlos contenidos a desarrollar, tanto a una clase de dos horas como de otra duración, realizando la selección de las actividades y los contenidos que se desee recortar o agregar. La que se presenta es sólo una posibilidad entre muchas.

Tal como se verá, se considera que su contenido es de utilidad para atender a cuestiones y problemáticas actuales, al mismo tiempo que permite enriquecer el conocimiento sobre las mismas. Dado que "la educación no es una isla, sino parte del continente de la cultura” (Bruner, 1991:29), debemos interrogarnos para qué sirve este contenido y el rol de cada de quienes trabajamos con él.

Las fuentes utilizadas para la preparación de esta clase son dos, a saber: a) una síntesis de la "Real Pragmática de hijos de familia” del año 1776, sancionada por el Rey Carlos III y que comenzará a aplicarse a las Indias dos años después; y b) un fragmento de la autobiografía de Ignacio Núñez. $\underline{2}$

Por otro lado, para explicar el contexto histórico de la época existen numerosas alternativas bibliográficas. Para este caso hemos utilizado a los textos de los siguientes autores: se ha utilizado la siguiente: Goldman, 1998: pp 25-31; Lobato \& Suriano, 2010: pp 99-104

Cabe destacar que la clase propiamente dicha se desarrollará a continuación de una previa en la que ya se han abordado temas relacionados con la primera unidad del diseño curricular anteriormente mencionado, a saber: “Crisis del orden colonial. Guerras de la Independencia”. Los contenidos 
específicos de la clase se encuentran en el punto 1 del mismo diseño, referidos a "La Sociedad tardo colonial. España en el siglo XVIII; Las reformas borbónicas y la reorganización del imperio. Se considera que las cuestiones trabajadas en la clase se pueden enmarcar en los ítems enunciados como "La realidad social del período” y "las redes de parentesco”. En una clase posterior, podría darse continuidad al tema, pero vinculándolo con los contenidos específicamente económicos ("Los intereses económicos de la Metrópoli y los intereses económicos de los españoles americanos” ; “Quiebre de redes de relaciones”)

\section{Propósitos y objetivos:}

Con esta clase se pretende estimular el acercamiento a los distintos tipos de documentos, para ofrecer una visión más amplia de la Historia, abordando temas como los referidos a la esfera social y cultural.

Además se busca explorar las problemáticas de la niñez, de la juventud, de las familias y del género, a través del aprendizaje de la diversidad en los contenidos de la historia que se propone desarrollar.

\section{Objetivo general}

Que los estudiantes logren comprender a las familias y sus relaciones como una parte constitutiva fundamental del campo social, en una época crucial de la transición hacia la modernidad vernácula.

\section{Objetivos específicos}

Reconocer a los diferentes actores sociales que se encuentran en los documentos.

Comprender los conceptos de familias, infancia, esposa, marido, etc., señalando las diferencias con la actualidad.

Identificar el tipo de problemas que presentaba la sociedad de la época.

Distinguir los estratos existentes dentro de la sociedad porteña y advertir las costumbres y los vínculos de los mismos.

\section{Desarrollo:}

\section{Recursos}

Los materiales utilizados son imágenes que muestran distintos tipos de familias pertenecientes al pasado y/o fotografías de familias actuales. Para ello se les pedirá a los estudiantes que busquen fotografías familiares o imágenes de familias que puedan ser expuestas el día de la clase.

En este ejercicio es crucial que los alumnos se conecten con sus emociones y sentimientos, ya que estos "están representados en los procesos de creación de significado y en nuestras construcciones de la realidad” (Bruner, 199:31). Al darle un sentido al contenido, su apropiación y manejo del tema será más fructífero.

Ejemplos de imágenes para utilizar como presentación son las siguientes: 


\section{Imagen 1}

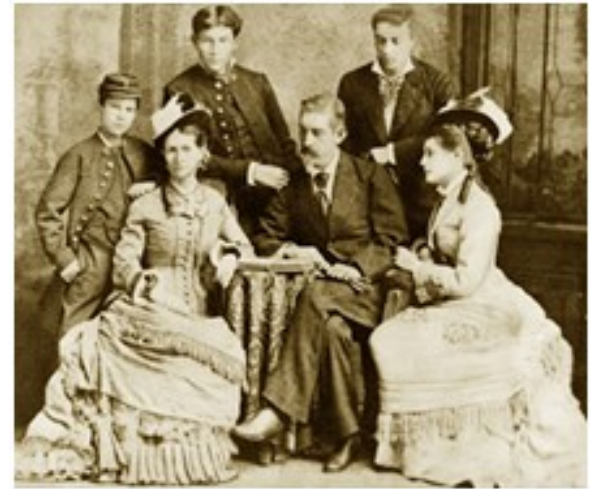

Alejo C. Jiménez Fernández junto a su familia, a mediados del siglo XIX en Costa Rica http://www.volcanazul.com/es/tradicion

Imagen 2

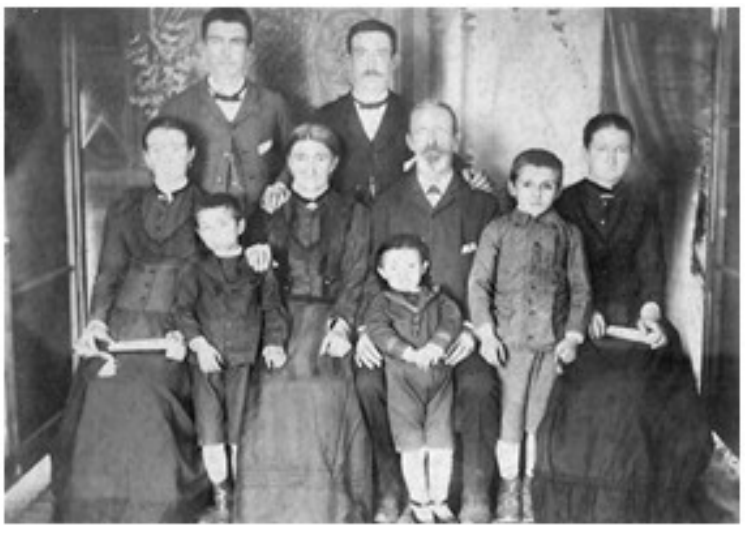

Foto de Miguel Graciano Itzaina y Juana Esponda con sus siete hijos http://itzaina.com/indexesp.html

\section{Imagen 3}

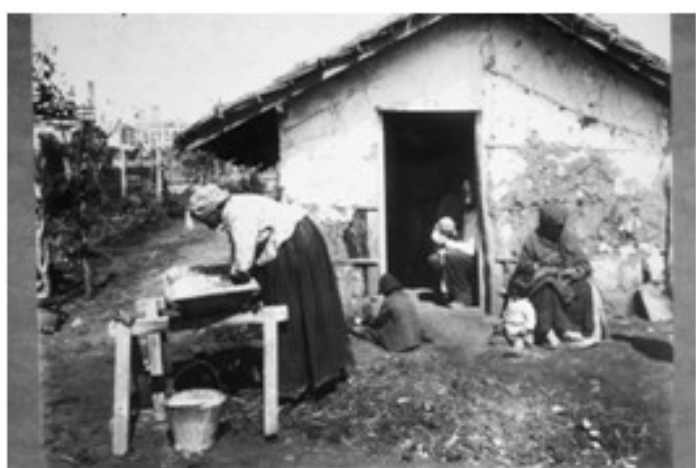

Vivienda de una familia afro, en Bs. As. A fines del Siglo XIX

http://jorgealgorta.blogspot.com.ar/2008/02/el-barrio-del-tambor.html

\section{Imagen 4}




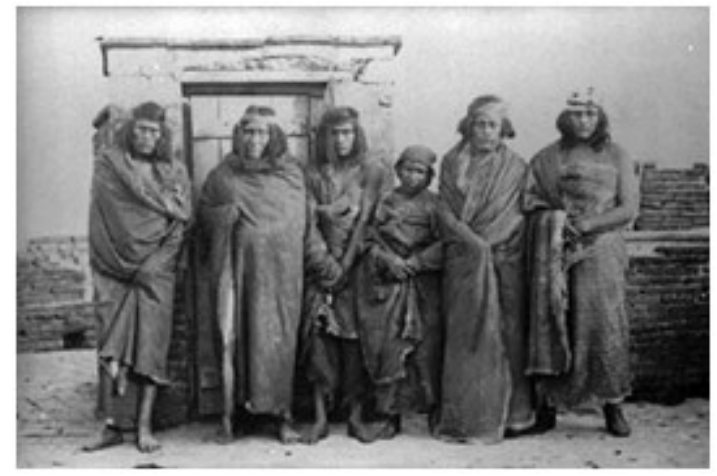

La Fotografía Italiana en la Argentina siglos XVIII / XIX Benito Panunzi

\section{Imagen 5}

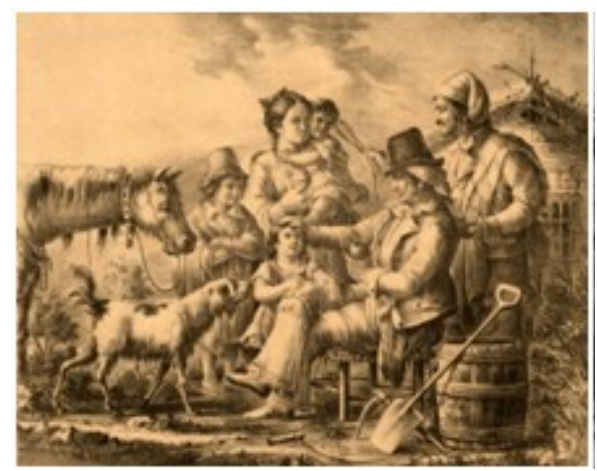

La familia del gaucho. http://caiana.caia.org.ar/template/caiana.php? pag=articles/article 2.php\&obj=115\&vol=3

\section{Imagen 6}

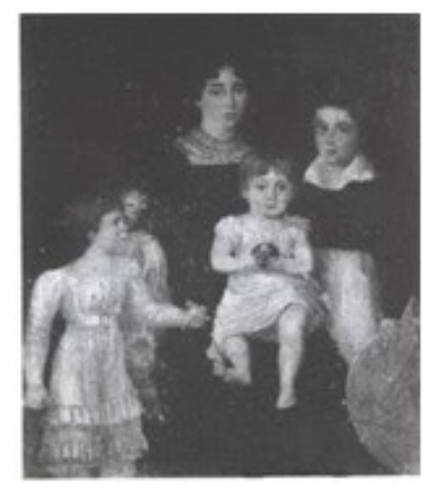

Mariquita Sánchez de Thompson e hijos

http://ellostambienamaron.blogspot.com.ar/2007/12/mariquita-sanchez-de-thompson.html 


\section{Imagen 7}

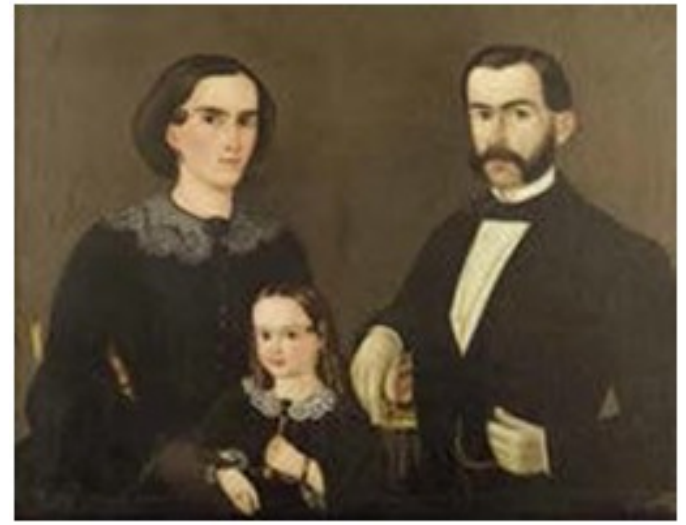

Retrato de Antonio Morales y familia, siglo XIX. Óleo José María Espinosa Prieto http://www.banrepcultural.org/blaavirtual/revistas/credencial/mayo2012/matrimonio-civil-en-elsiglo-XIX

Por otro lado, se contará con las dos fuentes escritas citadas y una ficha de cátedra elaborada a partir de diferentes autores que proporcionan un marco general del contexto, junto con el desarrollo de los conceptos de familia y niñez. Esta ficha brinda a los alumnos la información necesaria para el momento de abordar las fuentes (ver anexo $\mathrm{n}^{\circ} 3$ ).

\section{Desarrollo de la clase}

Tal como se dijo, la clase comenzará con un breve repaso del tema anterior. Esta tendrá en un principio, un carácter más explicativo - teórico por parte del docente; sin embargo, se espera que los alumnos refresquen los contenidos e interactúen formulando preguntas y/o comentarios.

En término generales el repaso se haría sobre la base de los siguientes contenidos:

A mediados del siglo XVIII en España, la Familia Borbónica, decidió emprender durante su reinado una reorganización profunda en el área administrativa y militar. Carlos III, uno de los representantes más fieles del despotismo ilustrado, pretendió subsanar las deficiencias financieras de España y promover su crecimiento a través de las colonias. Para ello, intensificó la relación entre la metrópoli con sus dominios y realizó una serie de reformas. Dentro de estas, se encontraron la reorganización política-administrativa-económica del imperio a través de, por ejemplo, la creación de los virreinatos de Nueva Granada (1740) y del Río de la Plata (1776) y de las Capitanías generales de Venezuela (1731) y Cuba (1764).

Para frenar la corrupción administrativa y los abusos de poder, se apeló a la reducción de la extensión de las unidades administrativas, el virreinato fue dividido en intendencias y se crearon también cuatro gobiernos político-militares: Montevideo, Misiones, Moxos y Chiquitos. 
Se determinaron las distintas funciones que debían cumplir y la subordinación de estos hacia el virrey. El régimen de intendencias estimuló la actividad de los cabildos que reclamaron mayor participación en el gobierno local. Esto generó por un lado conflictos entre intendentes y cabildos, pero por otro, la estimulación en la participación de tareas municipales.

La creación del virreinato en 1776, convirtió a la ciudad de Buenos Aires en la capital de un amplio territorio. Su posición fue clave para la lucha contra otras potencias como Inglaterra y Portugal. El fin era que América contara con un ejército propio, unificado, integrado por americanos y españoles.

Luego, como forma de introducir y sensibilizar sobre el tema propuesto, se observarán las imágenes de familias previamente colocadas en el pizarrón, estableciendo el año o el período aproximado al que pertenecen. Esta actividad introductoria, tiene como propósito generar que los estudiantes expresen lo que cada uno piensa, sabe o pueda decir sobre "las familias” observadas.

“Así, si interesa conocer e identificar las ideas de los alumnos es porque el objetivo general subyacente de la instrucción es lograr que el alumno comprenda los contenidos que tiene que aprender y no sólo que los memorice...” (Limón \& Carretero, 1997:29)

A través de dicha observación se busca establecer la diversidad en los tipos de familia (desde la familia nuclear, la familia extendida, hasta la más actual familia ensamblada) para llegar a los interrogantes sobre cómo eran las familias de fines del siglo XVIII y del XIX, cómo se establecían sus relaciones, cuáles eran las políticas y las normas que las alcanzaban, etc.

A continuación, se apelará a la ficha elaborada por el docente (previamente suministrada a cada uno de los estudiantes para que cuenten con la información necesaria para la realización de la siguiente actividad).Se dividirá la clase en dos, y al mismo tiempo, estas partes en grupos pequeños, para que se utilicen las mismas, de forma equitativa. Desde ese momento, el docente "orienta y guía explícitamente la actividad desplegada por los alumnos” (Díaz Barriga Arceo, 2003:110)

Cada uno de ellos nombrará a un redactor, a los fines de tomar nota a los diálogos que se produzcan internamente. Se distribuirán también las consignas correspondientes. Con ello se busca aplicar las ideas $^{3}$ que sostienen que los alumnos “...se apropian de las prácticas y herramientas culturales a través de la interacción con miembros más experimentados”, razón por la cual se priorizan los procesos que permiten "la negociación mutua de significados y la construcción conjunta de los saberes.” (Díaz Barriga Arceo, 2003:107)

Para finalizar se llevará a cabo una puesta en común a modo de corrección, en la que se espera ver cómo los alumnos fueron construyendo un concepto de familia, los cambios y las continuidades con nuestro tiempo, y cómo abordaron las fuentes, qué dificultades tuvieron, qué les pareció más interesante. 


\section{Actividades}

Como primer punto, los alumnos tendrán que identificar en la ficha, elementos de cambios y posibles continuidades en comparación con el presente. En segundo lugar, deberán responder preguntas que les servirán como una lectura guiada. Las mismas son breves y concisas, pero buscan que el alumno lea la fuente con mayor detalle.

Como última tarea, ellos deberán formular una pregunta, cuya respuesta puedan encontrarla en la fuente. Esta actividad busca desarrollar la creatividad en los alumnos, como también incentivarlos a participar del proceso de construcción histórico.

Las preguntas para trabajar con las fuentes son las siguientes:

1. Teniendo en cuenta la ficha y las fuentes responder:

Fuente 1: Nuñez

a. ¿¿n qué año nació el protagonista del relato?

b. ¿Cuál era la situación de sus padres? ¿ ¿Qué edad tenían sus padres al momento de su nacimiento? ¿Qué profesión tenían?

c. ¿¿A qué clase de hijos pertenecía?

d. ¿Quién lo crió?

e. ¿Cómo se relacionaría el tema de la infancia descripto en el texto y el ejemplo visto en la fuente?

Fuente 2: Real Pragmática

a. ¿Quién sanciona esta ley? ¿En qué fecha?

b. ¿Qué especifica?

c. ¿A quiénes perjudica?

d. ¿Qué consecuencias establece para aquellos que desobedezcan?

e. Teniendo en cuenta la ficha, ¿Qué idea se tenía del matrimonio? ¿Es la misma que se tiene en la actualidad?

2. Formular una pregunta que pueda responderse con la información brindada por el documento.

\section{Referencias Bibliográficas:}

Bruner, J. (1991). El estudio apropiado del hombre. En Actos de significado. Más allá de la revolución cognitiva. Madrid: Alianza. 
Carretero, M. (2009). Constructivismo y Educación. Buenos Aires: Paidós.

Cicerchia, Ricardo (1998). Historia de la vida privada en La Argentina, Buenos Aires: Troquel.

Cowen, M. Pablo. (2004). “Infancia, abandono y padres en el s. XIX porteño”, Anuario del Instituto de Historia Argentina, 4.

Díaz Barriga Arceo, F. (2003). Cognición situada y estrategias para el aprendizaje significativo. Revista electrónica de Investigación Educativa, 5 (2). Recuperado de: http://redie.ens.uabc.mx/vol5no2/contenido-arceo.html

Goldman, N. (1998). Nueva Historia Argentina. Revolución, República, Confederación (18061852). Tomo III. Buenos Aires: Sudamericana

Konetzke, Richard.(1962). Colección de documentos para la historia de la formación social de Hispanoamérica. 1493-1810, III, T. 1, Madrid, “Texto de la Pragmática Real de Hijos de Familia”.

Limón, M. , \& Carretero, M. (1997). M. Carretero (Comp.), Construir y enseñar las ciencias experimentales. Buenos Aires: Aique.

Lobato \& Suriano (2010). Nueva Historia Argentina. Atlas Histórico. Buenos Aires: Sudamericana Moreno, José Luis (2004). Historia de la familia en el Río de La Plata, Buenos Aires: Sudamericana.

Núñez, Ignacio. (1996). Autobiografía. Senado de la Nación - Academia Nacional de la Historia. Buenos Aires.

Quinteros, Guillermo O. (2015). La política del matrimonio. Novios, amantes y familias ante la justicia, Buenos Aires, 1776-1860, Rosario: Prohistoria. 


\section{Anexo 1}

\section{CAPÍTULO I*}

\section{NACIMIENTO E INFANCIA}

Debo mi existencia a una unión irregular, si hemos de atenernos a las costumbres que han formado leyes en la sociedad. Mis padres eran solteros cuando nací, comprometidos, como me lo han asegurado ellos mismos, a unirse por un contrato legal, que nunca se verificó, por motivos que no me ha tocado investigar. De este modo, pues, he quedado colocado en la segunda clase de la descendencia civil. La primera se denomina de hijos legitimos, esto es, nacidos de un matrimonio reconocido. La segunda de hijos naturales, habidos fuera del estado del matrimonio, pero cuyos padres estaban hábiles para celebrarlo al tiempo del nacimiento: esta segunda clase, que es a la que yo correspondo, tiene derechos, aunque inferiores a los de la primera, de que están enteramente privados los adúlteros y los incestos. Los tienen muy especialmente si son reconocidos, como lo he sido yo mismo por mis padres, en el Registro Pública de Nacidos que lleva la parroquia en que se me bautizó.

Nací en la calle Nueva, como se llamaba entonces la que hoy tiene el nombre de 25 de Mayo. La casa era propiedad de mis abuelos maternos. pasó después por diferentes manos, y al fin la compré yo mismo 43 años des. pués, cuando ya se distinguía con el $\mathrm{N}^{\circ} 157$. Mi madre, doña Catalina Conde, contaba entonces dieciocho primaveras: era hija de un español europero, natural de Asturias, nombrado don Juan Conde, que se ejercitaba en el comercio, y de una porteña nombrada doña Francisca de Paula Gadea, qué auxiliaba a su esposo en la compra y venta de los efectos; uno y otro de mis abuelos murieron con más de ochenta años de edad, conservando hasta sus últimos días un vigor extraordinario.

Mi padre, don Justo José Núñez, tendría como 25 años de edad cuando rací: había recibido una buena educación, y principiaba entonces a ejercitar la profesión de abogado con talentos no comunes.

* En la transcripción del manuscrito se ha actualizado la grafía, retocado la puntuación y desarrollado las abreviaturas. 
Él era hijo de un español, también asturiano, que había seguido por muchos años la carrera marítima, haciendo varios viajes a diferentes puntos del globo, v concluyendo por establecerse en Buenos Aires, donde compró y sirvió por sí mismo la escribanía del cuerpo municipal, a cuyo cargo estaba desde su origen el Registro Público de Hipotecas; mi abuelo se llamaba don Pedro Núñez. El estaba casado con doña Isabel Echevarría, natural de Buenos Aires, una de las señoras más preciosas de su tiempo, que se recomendaba igualmente por una esmerada educación. Mi abuelo murió de 64 años de edad, y mi abuela con más de 80 dejando en mi memoria los más justos motivos de estimación y gratitud.

Entre mis papeles se hallará el certificado de mi bautismo, con la declaración del reconocimiento de mis padres: nací el 30 de julio de 1792, y se me bautizó el día siguiente por el cura de la Catedral doctor don Juan Cayetano Fernández de Agüero, siendo la madrina mi propia abuela doña Francisca de Paula Gadea. La intervención en este acto de la misma madre de mi madre, demuestra que los compromisos de mis padres, que los había conducido a una comunicación ilícita, no exigían aquellas precauciones con que se conducen las relaciones que se forman y mantienen sin la intención de repararlas. En 25 de marzo de 1823, firmaron mis padres el reconocimiento que hicieron ante el cura de la misma parroquia doctor don Julián Segundo de Agüero, reproduciéndolo mi padre en su testamento de 17 de enero de 1827 , otorgado tres días antes de morir. No tanto por miramientos de decencia, ni porque mi madre no fuese de una constitución sana y robusta, sino por no privarse del tiempo que era necesario para los placeres, se encargó de criarme una nodriza, de origen indio llamada Florencia, casada con un hombre de color llamado Modesto, de oficio carpintero, esclavo de la comunidad de religiosos mercedarios, que existía entonces en la que ahora es parroquia de la Merced. Uno y otro vivieron bastante tiempo para que yo pudiese distinguir sus condiciones, y reconocer de algún modo el cuidado con que me trataron: uno y otro habían merecido por su conducta regular, las mayores distinciones no sólo de mis padres sino de todas las gentes de quienes estaban en dependencia; pero uno y otro mancharon los últimos años de su vida, entregándose a una multitud de vicios que dieron en tierra con su reputación y les trajo una vejez achacosa y pordiosera.

Aunque privado de los alimentos naturales de mi madre, ni ella ni mi padre descuidaron nada de lo que podía contribuir a la sanidad y a la ostentación de mi existencia. Se me preservó de la viruela, haciéndome inocular por el prebístero don Saturnino Segurola, que en su carácter privado adoptó 
este ejercicio benéfico en aquellas mismas circunstancias, cuando todavía no se administraba la vacuna en estas regiones.

Conservo por tradición la idea de la lujosa compostura de mis ajuares; $y$ si yo mismo he tenido este prurito en la mediocridad de mi fortuna, cuando se criaba mi hijo Julio, debo atribuirlo a las impresiones que me dejaban las repetidas historias que he oído referir a mi familia sobre los vestidos y sus colores, las alhajas y su valor, con que de continuo se me ostentaba en las funciones públicas, en las visitas, los bailes, los paseos, harto frecuentes entonces entre la familia de mi madre.

Cuando yo nací y me criaba de este modo, el mundo y mi patria se ocupaban de dos grandes incendios. El primero, que convirtió la Revolución Francesa en un teatro de los más espantosos horrores; y el segundo, que redujo a cenizas el único teatro dramático que se había conocido en Buenos Aires. La revolución de los franceses estalló el año de 1789 y desplegó su mayor furia en el de 1792. decapitando a su rey Luis XVI el 29 de enero de 1793 y levantando sobre sus ruinas el trono sanguinario de Robespierre, que asoló al pueblo de la Francia c hizo temblar todos los tronos del mundo. El incendio del teatro de Buenos Aires sólo fue de una materialidad funesta para los dos empresarios, uno de los cuales era don Francisco Velarde, deudo inmediato y muy relacionado con la familia de mi padre. Acababa de construirse el monasterio de capuchinas, o monjas de Santa Clara, que existe en esta ciudad con el nombre de San Juan. Se hicieron funciones en celebridad de su colocación, y la caña de uno de los cohetes voladores que se dispararon desde el mismo pórtico del templo distante como 300 varas del teatro cayó en él e incendió el techo que era de paja, como el de nuestros ranchos de la campaña. El teatro se hallaba en el mismo lugar donde hoy existe el principal mercado, y aun cuando la noche del incendio la concurrencia había sido numerosa, no sucedió más desgracia que la ruina total del edificio con toda la armadura dramatical. 


\section{Anexo 2}

\section{"PRAGMATICA SANCION PARA EVITAR EL ABUSO DE CONTRAER MATRIMONIOS} DESIGUALES. El Pardo, 23 de marzo de 1776.

El Rey. Por cuanto con el fin de evitar los contratos de esponsales y matrimonios que se ejecutaban por los menores e hijos de familias sin el consejo de sus padres, abuelos, deudos o tutores, de que resultan graves ofensas a Dios, nuestro Señor, discordias en las familias, escándalos y otros gravísimos inconvenientes en lo moral y político, tuve por conveniente establecer en estos mis Reinos y dominios de España la Pragmática Sanción de 23 de marzo de 1776, que es del tenor siguiente.

... Y habiendo llegado a ser tan frecuente el abuso de contraer matrimonios desiguales los hijos de familias, sin esperar el consejo y consentimiento paterno ... que con otros gravísimos daños y ofensas a Dios resultan la turbación del buen orden del Estado y continuadas discordias y perjuicios de las familias, contra la intención y piadoso espíritu de la Iglesia, que aunque no anula ni dirime semejantes matrimonios, siempre los ha detestado y prohibido como opuestos al honor, respeto y obediencia que deben los hijos prestar a sus padres en materia de tanta gravedad e importancia.

Y no habiéndose podido evitar hasta ahora este frecuente desorden por no hallarse específicamente declaradas las penas civiles en que incurran los contraventores, he mandado esta materia con la reflexión y madurez que exige su importancia ...

... he tenido por bien expedir esta mi carta y Pragmática Sanción en fuerza de ley, que quiero tenga el mismo vigor que si fuese promulgada en Cortes.

... los tales hijos e hijas de familias menores de 25 años deban para celebrar el contrato de esponsales pedir y obtener el consejo y consentimiento de su padre y en su defecto de la madre; y a falta de ambos de los abuelos por ambas líneas, respectivamente, y no teniéndolos, de los dos parientes más cercanos que se hallen en la mayor de edad y no sean interesados o aspirantes al tal matrimonio; y no habiéndolos capaces de darle, de los tutores o curadores su consentimiento deberán ejecutarlo con aprobación del juez real.

2. Que esta obligación comprenda desde las más altas clases del Estado sin excepción alguna hasta las más comunes del pueblo, porque en todas ellas sin diferencia tiene lugar la indispensable y natural obligación del respeto a los padres y mayores que estén en su lugar por derecho natural y divino y por la gravedad de la elección de estado con persona conveniente; cuyo discernimiento no puede fiarse a los hijos de familias y menores, sin que intervenga la deliberación y consentimiento paterno, para reflexionar las consecuencias y atajar con tiempo las resultas turbativas y perjudiciales al público y a las familias.

3. Si llegase a celebrarse al matrimonio sin el referido consentimiento o consejo, por este mero hecho así los que lo contrajeren como los hijos y descendientes que provinieren del tal matrimonio, queden inhábiles y privados de todos los efectos civiles, como son el derecho a pedir dote o legítimas y de suceder como herederos forzosos y necesarios en los bienes libres que pudieran 
corresponderles por herencia de sus padres o abuelos, a cuyo respeto y obediencia faltaron contra lo dispuesta en esta Pragmática, declarando como declaro por justa causa de su desheredación la expresada contravención e ingratitud para que no puedan pedir en juicio, ni alegar de inoficioso o nulo el testamento de sus padres o ascendientes, quedando éstos en libre arbitrio y facultad de disponer de dichos bienes a su voluntad y sin más obligación que la de los precisos y correspondientes alimentos.

4. Asimismo declaro que en cuanto a los vínculos, patronatos y demás derechos perpetuos de la familia que poseyeren los contraventores o a quien tuvieren derecho de suceder, queden privados de su goce y sucesión respectiva; ...

6. Los mayores de 25 años cumplen con pedir el consejo paterno para colocarse en estado de matrimonio, que en aquella edad ya no admite dilación, como está prevenido en otras leyes; pero si contravinieren dejando de pedir este consejo paterno incurrirán en las mismas penas que quedan establecidas así en cuanto a los bienes libres como en los vinculados.

7. Siendo mi intención y voluntad en la disposición de esta Pragmática el conservar a los padres de familias la debida y arreglada autoridad que por todos derechos les corresponde en la intervención y consentimiento de los matrimonios de sus hijos y debiendo dirigirse y ordenarse la dicha autoridad a procurar el mayor bien y utilidad de los mismos hijos de sus familias y del Estado, es justo precaver al mismo tiempo el abuso y exceso en que pueden incurrir los padres y parientes en agravio y perjuicio de arbitrio y libertad que tienen los hijos para la elección del estado a que su vocación los llama; y en caso de ser el de matrimonio para que no se les obligue, ni precise a casarse con persona determinada contra su voluntad, pues ha manifestado la experiencia que muchas veces los padres y parientes por fines particulares e intereses privados intentan impedir que los hijos se casen y los destinan a otro estado contra su voluntad y vocación, o se resiste a consentir en el matrimonio justo y honesto que desean contraer sus hijos queriéndolos casar violentamente con persona a que tienen repugnancia, atendiendo regularmente más a las conveniencias temporales que a los altos fines para que fue instituído el santo sacramento del matrimonio.

8. Y habiendo considerado los gravísimos perjuicios temporales y espirituales que resultan a la república civil y cristiana de impedirse los matrimonios justos y honestos o de celebrarse sin la debida libertad y recíproco afecto de los contrayentes, declaro y mando que los padres, ... deban precisamente prestar su consentimiento si no tuvieren justa y racional causa para negarlo, como lo sería si el tal matrimonio ofendiese gravemente al honor de la familia o perjudicase al Estado.

9. Y así contra el irracional disenso de los padres, ... debe haber y admitirse libremente recurso sumario a la justicia real ordinaria, el cual se haya determinar y resolver en el preciso término de ocho días, y por recurso en el Consejo, Chancillería o Audiencia del respectivo territorio en el perentorio de 30 días, y de la declaración que se hiciese, no haya revista, alzada, ni otro recurso por deberse finalizar con un solo auto, ora confirme o revoque la providencia del inferior a fin de que no se dilate la celebración de los matrimonios racionales y justos.

10. Que sólo se pueda dar certificación del auto favorable o adverso, pero no de las objeciones y excepciones que propusieren las partes, para evitar difamaciones de personas familias; y sea 
puramente extrajudicial e informativo semejante proceso, y aunque se oiga a las partes en él por escrito o verbalmente, sea siempre a puerta cerrada...

11. Mando asimismo se conserve en los Infantes y Grandes la costumbre y obligación de darme cuenta y a los Reyes, mis sucesores, de los contratos matrimoniales que intenten celebrar ellos o sus hijos e inmediatos sucesores, para obtener mi Real aprobación; ...”

Fuente: Konetzke, Richard. Op. Cit., vol. III, tomo 1, pp. 406-413.

\section{Anexo 3}

\section{La Sociedad porteña y sus conformaciones familiares}

- Después de leer el texto, identificar tres elementos de cambio y las posibles continuidades que se observen.

El concepto de familia ha ido cambiando a lo largo del tiempo, esto se observa en el número de miembros que la conforman, los tipos de vínculos y sus costumbres, entre otras cosas.

Hacia fines del siglo XVIII y principios del XIX, existieron tanto familias nucleares, esposos e hijos, como familias extensas, esposos, hijos y otras personas. Estas últimas podían ser tanto familiares de otras generaciones, abuelos, tíos, primos, como personas que carecían de lazo sanguíneo, pero eran puestas bajo tutela de una familia.

Según datos censales, había una correlación entre número de hijos y la situación económica. Las familias más acomodadas solían ser más extensas que el resto de los sectores. La mayoría de la población elegía las familias pequeñas.

Los datos censales también han revelado que en numerosos casos quien estaba al frente del hogar era una mujer. Esta no correspondía únicamente al ideal de mujer Esposa -Madre, sino que algunas eran solteras, separadas o viudas.

\section{Vínculos, leyes y conflictos:}

En 1776, el monarca español estableció la sanción de la Real Pragmática, que consistió en la obtención del consentimiento paterno para la formalización de los matrimonios de menores de 25 años. Para aquellos que su padre estaba ausente, era la madre o el tutor quien ejercía dicha atribución. Quienes no cumplían con la norma, se verían afectados por una sanción y privados de los bienes heredados. Esta ley provocó la ampliación de la jurisdicción del Estado sobre los asuntos familiares y llevó a recortar el papel de la Iglesia. 
La Pragmática, generó aceptación y rechazo. Los primeros juicios de disenso (desacuerdo) empezaron hacia el año 1779.

Si bien se concebía la idea del matrimonio como una institución caracterizada por la monogamia; la heterosexualidad y la indisolubilidad del vínculo, en la cotidianidad se vivían otras situaciones. El Adulterio, el amancebamiento y el incesto eran considerados delitos graves.

Muchas fueron las mujeres que se presentaron ante la justicia para reclamar y denunciar. La “irresponsabilidad” del hombre fue la causa más destacada. Ejemplo de conflictos relacionados a este tema fueron los hijos; alimentos y buenos modales. También en las fuentes se observan situaciones de irregularidad, como concubinos, hijos ilegítimos (quienes nacieron fuera del matrimonio católico).

Otro caso, aparecido en los archivos judiciales se vinculó con el abandono de menores. Allí se ven tanto la figura de la cesión de menores como el reclamo de recuperación de los hijos cuando la situación de la familia original se encontraba estable. Esta última podía ocurrir cuando a la familia que adoptaba se la denunciaba por incumplimiento de sus obligaciones para con el menor.

Para quienes tenían niños nacidos de relaciones no aprobadas, contaban con la posibilidad de dejarlos en una institución.

“... era sano para el bien común ocultar o tratar en forma lo suficientemente discreta, sin esconder prácticas que por comunes eran tenidas como irremediables” (Cowen, 2004:76)

La primera Casa de Niños Expósitos de Buenos Aires comenzó a funcionar en 1779.

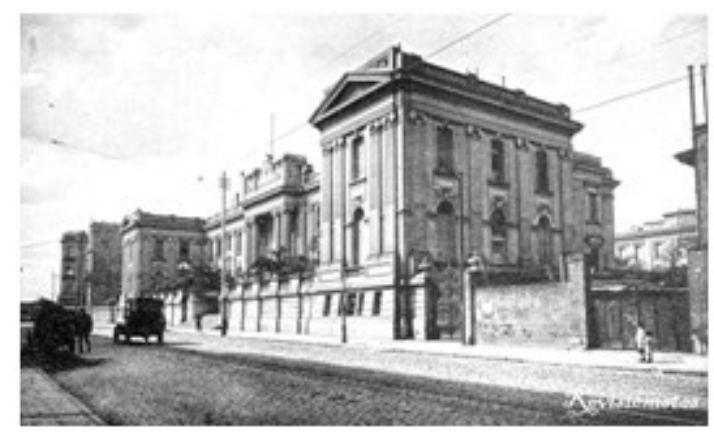

\section{Adultos pequeños:}

La idea de "Niñez", como se la conoce en la actualidad, no existía en el siglo XIX. El niño, era un sujeto invisible para la sociedad. En todo caso, se entendía a esta etapa como una "transición a la adultez"

Era alguien que debía ser educado, había que inculcarle conocimientos. Esta educación estuvo relacionada con la evangelización, por lo tanto los valores morales eran importantes para su formación.

Cuando el niño nacía, una de las primeras cosas que se hacían era el Bautismo, dentro de los primeros diez días, pese a esto, muchos registros parroquiales mencionan que se los bautizaba más 
tarde de lo recomendado.

Los niños fueron un grupo social muy vulnerable. Al ser escasos sus derechos reconocidos, quedaban al total desamparo.

"La infancia se puede caracterizar, entre otros aspectos, por su fragilidad, dada por su condición de desarrollo físico-psíquico incompleto y que por lo tanto deja un apreciable margen para ser visto como sujeto “fácilmente abusable”...” (Cowen, 2004:76)

Se registró para esta época, una alta mortalidad infantil, ocasionada por múltiples factores, mala alimentación tanto de la madre como del niño; falta de cuidados, uniones sexuales relativamente libres e inestables (provocó la muerte de adultos); malos procedimientos al momento del parto, falta de higiene (para ambos).

También fueron víctimas del abandono:

"Los testimonios sobre niños abandonados y devorados por las incontables alimañas que tenían por hábitat las calles y casas de Buenos Aires son innumerables; en el barrio de San Miguel, se hallaron dos criaturas, una comida por un perro y otra por los cerdos...” (Cowen, 2004: 85)

Ante la muerte o el rechazo de sus progenitores, el destino era una institución o la adopción de una familia. Esta última, no siempre se concretó de forma gratuita, dado que muchos debieron trabajar ya desde los 5 años, ya que constituían mano de obra barata.

Fue bastante común la entrega de menores “en depósito” a otras familias para su educación y mantenimiento. En el caso de las mujeres, muchas eran enviadas a trabajar en el ámbito doméstico.

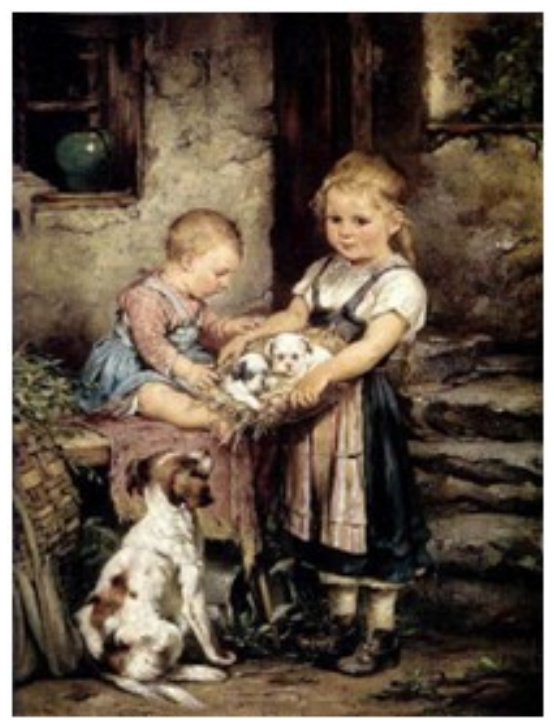

¿Cómo era la relación entre padres e hijos?

Las expresiones de afecto como conocemos hoy en día, fueron muy escazas. A mitad del siglo XIX comienza a cambiar la forma de dirigirse hacia los hijos. El maltrato era muy frecuente, como las denuncias. Pero los niños no podían declarar frente al juez, por lo tanto su madre era quien hablaba 
por ellos.

\section{Notas}

1 La idea que se expone surgió en el marco del Taller de Enseñanza de la Historia dictado por los Profesores Pablo Cowen y Guillermo O Quinteros en 2016. Agradezco enormemente los comentarios críticos y la ayuda proporcionada por dichos docentes a lo largo de la elaboración de este trabajo.

2 L La Pragmática se encuentra en Konetzke, 1962: 406 y la del fragmento de la Autobiografía se extrajo de Núñez, 1996: 35-37. Ver anexo 1 y2

$\underline{3}$ Un modelo de enseñanza situada, busca utilizar estrategias que promuevan un aprendizaje colaborativo o recíproco. (Díaz Barriga Arceo, 2003:107)

\section{Bibliografía:}

Cicerchia, Ricardo (1998). Historia de la vida privada en La Argentina, Buenos Aires: Troquel, Pp, 55-91

Cowen, M. Pablo (2004). “Infancia, abandono y padres en el s. XIX porteño”. Anuario del Instituto de Historia Argentina, 4.

Moreno, José Luis (2004). Historia de la familia en el Río de La Plata, Buenos Aires: Sudamericana.

Quinteros, Guillermo O. (2015). La política del matrimonio. Novios, amantes y familias ante la justicia, Buenos Aires, 1776-1860, Rosario: Prohistoria. Pp. 37-75 